\title{
Evaluation on the Significance and Shortcomings of German Functionalist Vermeer's Skopos Theory
}

\author{
Miaomiao Yang \\ East China University of Science and Technology, Shanghai, China \\ Email: 1975285438@qq.com
}

How to cite this paper: Yang, M.M. (2020) Evaluation on the Significance and Shortcomings of German Functionalist Vermeer's Skopos Theory. Open Access Library Journal, 7: e6923.

https://doi.org/10.4236/oalib.1106923

Received: October 23, 2020

Accepted: November 23, 2020

Published: November 26, 2020

Copyright $\odot 2020$ by author(s) and Open Access Library Inc.

This work is licensed under the Creative Commons Attribution International License (CC BY 4.0).

http://creativecommons.org/licenses/by/4.0/

\begin{abstract}
Vermeer's Skopos Theory has much significance. It gives us a new way of thinking about the concept of translation and the role of translator and target reader in the translation process. However, it also has some shortcomings, including the ambiguity of the "skopos", the undervaluation of source text and writer, the unfalsifiability of Skopos Theory and the ambiguity of evaluation criteria for the target text.
\end{abstract}

\section{Subject Areas \\ Linguistics}

Keywords

Skopos Theory, Critical Thinking, Significance, Shortcoming

\section{Introduction}

Vermeer thinks that translation, as an aspect of human action, is purposeful or intentional, and that the purpose (skopos) of this translation action is very important as it determines the translation strategies and translation methods in the later translation activity of the translator, which is the most important rule of Skopos Theory-the skopos rule. Besides, Vermeer also puts forward the other two rules-the coherence rule and the fidelity rule and states clearly the hierarchical order of these 3 rules-skopos rule $>$ coherence rule $>$ fidelity rule. Skopos Theory gives us a new way of thinking about the concept of translation and the role of translator and target reader in the translation process. However, it also has some shortcomings. This paper is going to have a critical thinking about 
Vermeer's Skopos Theory, mainly focusing on the shortcomings of Skopos Theory.

\section{Key Concepts in Vermeer's Skopos Theory}

Skopos Theory is a very important part of German functional translation theories. In Groundwork for a General Theory of Translation, Reiss and Vermeer combine's their two theories-Vermeer's Skopos Theory and Reiss's text-type model together, hoping to create a general theory for translation. This book is Vermeer's major work on Skopos Theory, in which Vermeer gives a detailed explanation of his Skopos Theory. Enlightened by Wright ${ }^{1}$, Vermeer regards translation as a mere linguistic process, but a communicative process, in which verbal and non-verbal signs is transferred (Nord, 2001) [1]. Vermeer holds that the skopos of translation is paramount, and that it determines the translation methods and translation strategies of the translators, which is the famous skopos rule, also the central idea of Vermeer's Skopos Theory. In order to have a critical thinking about Skopos Theory and give a critical evaluation, we must firstly understand Vermeer's Skopos Theory.

\subsection{Translation Action}

Enlightened by Wright's action theory, which regards human's action as intentional, Vermeer sees translation as a human action, meaning that translation is an intentional action performed by human being. In his $A$ Framework for a General Theory of Translation, Vermeer describes translation as a communicative action (intentional), in which communicative verbal and nonverbal signs are transferred from one language into another (Nord, 2001) [1]. Vermeer claims that seeing translation as a mere linguistic process is not adequate, this is also an important significance of Vermeer's Skopos Theory, a shift from previous linguistic translation theories. "Linguistic alone won't help us. First, because translating is not merely and not even primarily a linguistic process. Secondly, because linguistic has not yet formulated the right questions to tackle our problems. So, let's look somewhere else." (Vermeer, 1987) [3].

Vermeer's opinion is similar to another German functionalist-Justa Holz-Manttari. In her book, she puts forward the translation action model, and defines "11 translation action" as "a complex action designed to achieve a particular purpose" (Holz-Manttari, 1984) [4]. Traditionally, people regard translation as the activity of only translators. Holz-Manttari expands the traditional thinking of the circle of the participations of translation. She views translation as a communicative process involving a series of roles and players, including the initiator, the commissioner, the ST producer, the TT producer, the TT user, the TT receiver, in her translational action model (Holz-Manttari, 1984) [4].

${ }^{1}$ G.H. von Wright puts forward the theory of action theory. He regards action as consciously creating or intervening changes of the world. In his action theory, von Wright explains action from the perspective of the reason or purpose of a specific action, and the implementation of an action is deemed as the way to achieve a specific purpose [2]. 
Vermeer's Skopos Theory and Holz-Manttari's translation model have a lot in common, so that Jeremy in his Introducing Translation Studies comments that "Although Skopos Theory predates Holz-Manttari's theory of translation action, it can be considered to be part of that same theory, and it deals with a translational action which is ST-based, which has to be negotiated and performed, and which has a purpose and result" (Jeremy, 2001) [5].

So both Vermeer and Holz-Manttari regard translation as an intentional (purposeful) and communicative human action, and intention or purpose is the source of the word "skopos". To state clearly and avoid confusions, in this article, the translation work performed merely by translators will be called translation work or translation activity, and "translational action" or "translation action" will be the special term for Holz-Manttari and Vermeer's understanding of broader scope of translation.

\subsection{Skopos Theory}

"Skopos" is a Greek word, meaning "aim" or "purpose" and is introduced by Vermeer into his "Skopos Theory", implying that Hans J. Vermeer agrees that translation action, as a human action is with a purpose or intention. So what's the source of the skopos of a specific translation actin, and how to determine it?

According to Vermeer, commission is the source of the skopos of a specific translation action. A commissioner needs to state clearly the commission of the translator, including the goal and the conditions under which the goal should be achieved (including the fee and deadline). The commission is the source of the skopos of a specific translation action.

According to different translation skopos or different translation commission, translators can choose their own translation strategies or methods to achieve their skopos. In other words, the skopos of translation determines the translation methods and translation strategies in the later translation work of the translator. To differentiate his theory from Nida's equivalence theory, Vermeer puts forward his new understanding of translation criteria-adequacy. Adequacy describes the relations between ST and TT, if the skopos of a specific translational action is achieved, then the result of a translational action-the translatum or TT is adequate, otherwise it is not. And Vermeer and Reiss regard Nida's equivalence as a special branch of adequacy if the skopos is the same for ST and TT (Vermeer and Reiss, 1984) [6].

According to Vermeer, the skopos of a translational action determines the TT, which is the Rule 1 -the skopos rule. Besides, there are other two important theories in Vermeer's Skopos Theory, the intratextual coherence rule (or the coherence rule) and the intertextual coherence rule (or the fidelity rule). Intratextual coherence rule, also the coherence rule, requires that the target text must be translated in such a way that it is coherent with the circumstances and knowledge of the target text receivers. In other words, the target text must make sense in the target language and it should be readable and fluent in the target language. 
Intertextual rule, also the fidelity, requires that there must be coherence between the source text and the target text. In detail, there must be coherence between the source text information received by the translator, the interpretation the translator makes of this information and the information that is encoded for the TT receivers (Jeremy, 2001) [5].

Vermeer claims that there is a clear hierarchical order of these three rules: skopos rule $>$ coherence rule $>$ fidelity rule. The skopos rule is dominating and the most important rule in translation activity, and the other two rules are both subordinated to skopos rule. In other words, if the other two rules are contradicted to the skopos rule, translators should obey the skopos rule and can violate the other two rules, the skopos rule and the fidelity rule. For coherence rule and fidelity rule, Vermeer puts coherence rule ahead of the fidelity rule and he gives the least importance to the fidelity rule, which is the most important reason for him being criticized.

\section{A Critical Thinking about Skopos Theory}

\subsection{Different Comments on Skopos Theory}

As a very important part of German functional translation theories, Skopos Theory marks a shift of the focus of translation from the mere linguistic level to a functional level. It provides a new perspective to see translation, but unavoidably, it also has some shortcomings. Since the appearance of Vermeer's Skopos Theory, it arises a lot of comments.

Nord and Schaffner discussed some of the criticism of Vermeer's Skopos Theory, mainly the following. The first is that the "general" theory is in fact only valid for non-literary texts. The second is that Reiss's text type approach and Vermeer's Skopos Theory cannot be lumped together. The third one is that Skopos Theory does not pay sufficient to the linguistic nature of ST or to the reproduction of microlevel features in the TT (Jeremy, 2001) [5].

In Pym's Exploring Translation Theories, Pym gives a comprehensive and objective comment on Skopos Theory. Pym thinks that Skopos Theory, as a very important theory, firstly, gives a new interpretation of translators. Besides, the skopos rule marks a shift of translation from mere linguistic level to a more complex level, in which society and culture should be considered. Third, it gives us a new understanding of the concept of translation. Fourth, it puts forward the new criteria of translation work. But Skopos Theory also has its inherent shortcomings. First, the "skopos" is an ideal concept. Second, it is unfalsifiable. Third, equivalence becomes a specific example of adequacy. Fourth, it is impractical for the translator to take a lot of time to negotiate with his clients (王鹏, 2010) [7].

Nan Feng Zhang also talks about the contributions and limitations of Skopos Theory, and further explains it by giving specific translation examples. He also concludes the previous question of Skopos Theory. He thinks that Skopos Theory, as other general translation theories, have all kinds of problem in that they want to tackle the translation problem from a macro level, however, failing 
to prove their eternity (张南峰, 2004) [8].

Da Liang Chen gives his critical thinking of Skopos Theory in terms of different phases in the process of translational action: the intercultural communication phase before translation, the translation phase and the evaluation phase after translation phase, and gives his opinion about the range of application of Skopos Theory (陈大亮, 2007) [9].

\subsection{Significance of Skopos Theory}

Skopos Theory brings us a new thinking about translation, translation evaluation criteria. It liberates the translators and recognizes the needs of the target reader to some extent. And it also has some shortcomings, and this chapter is going to give a critical thinking about Skopos Theory by talking briefly about the significance and the shortcomings of Skopos Theory in detail.

First, Skopos Theory marks a shift of translation theory from a mere linguistic level to a more complex level. In Skopos Theory, translational action is regarded as a communicative human action, in which the social elements and cultural elements of the source text should be considered. Instead of considering the mere linguistic level, other cultural elements are considered; this is a significance of Vermeer's Skopos Theory.

Second, Skopos Theory makes people have a new thinking about the involving participants of a translational action. Traditionally, people regard translation as the interaction between translators and the source text, or translators between the writers. However, Vermeer, regards translation as an intentional human action with a purpose and regards the commission as the source of a translation. Besides the commissioner, the clients, the target reader and so on are considered in the process of a translational action. Instead of merely being loyal to the source text or the original writer, translator should be loyal to his commissioner, his clients, and his target reader.

Third, Skopos Theory gives the translator more freedom. In the past, translators are compared to dancers in ankle cuffs. They have to be loyal or faithful to the source text, and try as possible as they can to convey the meanings of the writers to achieve equivalence to the source texts. However, in the Skopos Theory, skopos rule is paramount and if the fidelity rule is contradicted to the skopos rule, translators can choose to delete or rewrite the source text according to their different skopos.

Fourth, it gives a new criterion for translation evaluation. Instead of being equivalent to and transferring the meaning of the source, Vermeer points out that if a translation work satisfies its skopos, then it is adequate and good translation even if it is not equivalent to the source text. Equivalency is only a sub-branch of adequacy.

Fifth, Skopos Theory gives certain attention to the target reader. Instead of being fluent, the coherence rule of Skopos Theory states that the conditions and knowledge of the target reader should be considered to achieve intratextual co- 
herence. Target reader's different needs are recognized and translators should take them into consideration.

\subsection{Shortcomings of Skopos Theory}

Skopos Theory has much significance, as stated in 3.1. However, it also has some shortcomings. The skopos is an ambiguous concept. Skopos Theory undervalues the source text and writers. Skopos Theory is unfalsifiable and Skopos Theory fails to give clear evaluation criteria for a translation.

\subsubsection{The Ambiguity of "Skopos"}

According to Vermeer's Skopos Theory, the most important thing in a translation work is the skopos. Vermeer puts forward the new evaluation criteria for a certain translation-adequacy. Since sometimes the skopos of source text and target text is different, so the translation should be allowed to be not equivalent. In this case, if a translation work achieves its skopos, then it is appropriate and adequate. So knowing clearly the skopos of a translation work is very important in evaluating whether a translation work is adequate or not. However, one shortcoming of Vermeer's Skopos Theory is that the concept of skopos is ambiguous.

In Skopos Theory, Vermeer regards translation as a human action, which is intentional and purposeful. When the skopos of the target text is different from the skopos of the source text, translator can choose to be not equivalent with the source text if in accordance with the skopos. And here comes one problem, whether all the source text and all the translation are intentional or purposeful, which is still in dispute. Sometimes writers produce "art" for "art's sake" and maybe some translations are done with no purpose. So in these situations, can Skopos Theory still be applied and how to explain them?

According to Skopos Theory, in the normal circumstances, a client needs a translation work and then the client should come to the translator with a "translation brief" or "commission". In the translation brief or the commission, the client should give as many details as possible such as the skopos, time, addressee, time, place, and medium of the target text. The skopos of the translation work should be clarified in the translation commission so that the translator could know clearly the skopos and appropriate translation methods and translation strategies could be utilized in the translation work. So the client plays the role of initiator in the translation process and determines the skopos of the translation work. And the client and the translator could negotiate with each other to help clearly convey the skopos of the translation work and negotiation between clients and translators is needed especially when the client has only a vague or even an incorrect idea of the what kind of text is required (Nord, 2001) [1].

So according to the previous analysis, we know that in Vermeer's Skopos Theory, the source of the skopos of a translation is the commission, which should be drafted by the client or the commissioner. However, in the normal situation, the clients do not know the Skopos Theory and do not know the im- 
portant role of translation commission, and they can only give a brief introduction of the target text in their mind to the translators. In the reality, most of the time, the clients are not experts in translation and they do not have the competence to list practical and feasible requirements of the target text. And sometimes there is even no written translation commission by the clients for the translators. Clients' negotiation with translators is only an ideal situation but not feasible or practical in the reality. It may take a lot of effort of the translators and the clients but may lead to low efficiency and the waste of time.

So here comes one contradictory phenomenon. On the one hand, the Skopos Theory requires that the skopos of the translation work should be determined by the clients and displayed clearly in the translation brief. On the other hand, there is only a brief introduction of the requirements for the target text and sometimes there is even no written translation commission. So the skopos of the translation work has no substantive contents. The translators can only depend on themselves to deduce the possible skopos of the target text and depend on themselves to decide the translation strategies and translation methods in the later practical translation work. This gives a lot of freedom to the translator, however, at the same time, makes the skopos of the translation commission a meaningless and ambiguous concept in the practical translation work of the translators.

From the above analysis, we can conclude that the skopos of a translation work is only an ideal and ambiguous concept and has no guiding significance in the later practical translation work of the translator, which is one very important shortcoming of Vermeer's Skopos Theory.

\subsubsection{The Undervaluation of Source Text and Writer}

Vermeer claims that due to different skopos of a specific translation work, the translator could choose different translation methods and translation strategies. Even the translator rewrites or deletes the source text is feasible if it is in accordance with the skopos. Equivalence should not be the translation criteria for the target text but adequacy should, and equivalence is categorized to be a branch of adequacy, when the skopos of the target text and the source text are almost the same.

In Vermeer's Skopos Theory, there are 3 important rules: the skopos rule, the coherence rule and the fidelity rule, which have been discussed in detail in 1.2. We know that the hierarchical rule of these three rules is that skopos rule $>$ coherence rule $>$ fidelity rule. So Vermeer puts the fidelity rule into the least important role in these three rules, very different from Nida's equivalence theory and Yan Fu's “信达雅”, which put the source text and writer at a very important place. This proposition gives a lot of freedom and subjectivity to translators, and translators are entitled to rewrite or even delete some of the source text. Source text is only regarded to be an "offer of information" in a source culture and source language, and too much freedom leads to disrespect of the source text and the writers.

Skopos Theory treats translation as a functional activity and too much free- 
dom and subjectivity of the translator leads to low respect for the source text and writer. When in the translation of literary works, being too much goal-oriented and deleting, rewriting and simplification of the source text would destroy the literariness and artistry of the original literary work.

High freedom of the translators and low respect for the source text and writer is feasible in some cases where the author's copyright is uninvolved, such as advertisement and the product manual. However, for the translation of some literary works where the author's copyright is involved, conflict may occur if the translators show little respect for the source text and the writers. For example, when James Joyce heard that someone was going to translate his Ulysses, he requires that there should be no alteration for the translation of Ulysses (王振平, 2006) [10]. So in this kind of situation, when the author asks to respect his or her copyright, how the translator should handle it and how to balance between the skopos of the initiator and the copyright of the author? Though Vermeer argues that respecting the source text may be one skopos of the initiator, such cases are very limited.

Mi Qing Liu points out that since translation hopes to achieve the successful communication, then in the process of communication, both of the sides should be attached with enough importance. The translators should be paid due attention to the content and skopos of the source text and target text. Too much focus on the skopos decided by the initiator endows translation with too much commercial nature or commercial character, and in this process, not only the source text and the original is undervalued, readers are despoiled of the right of communication (刘宓庆, 2005) [11].

Vermeer puts skopos at a paramount place, and too much commercial are endowed to the process of translation. This proposition gives the translators a lot of freedom and subjectivity, however, undervalues the source text and the writer. This is practical for these writings in which copyright is uninvolved, but not feasible for the translation of writings in which copyright is involved, such as the translation of literary works. The literariness and artistry of the original literary work may be destroyed and conflict may occur.

\subsubsection{The Unfalsifiability of Skopos Theory}

Vermeer claims that the skopos is regulated by the initiator at first but finally determined by the translators. So should the translators be the ones who judge whether his or her translation has achieved the skopos? How do we know the skopos of the translators and how we prove that the translators fail to achieve the skopos? Let's see an example.

原文：改革进入了深水区，但再深的水我们也得蹚。

译文: In pursuing reform, we have entered uncharted/deep waters. But we must wade through these waters no matter how deep we are.

This example is from Translators Association of China, in its website. The word “深水区” means that China's reform has entered its journey of the middle of a river, a very critical point of China's reform. In English, "uncharted waters" 
may be an acceptable translation, however, "deep water" gives people an impression of limited hope to survive. Since Translators Association of China puts this version of translation in its website, at that time they think that this translation is acceptable and appropriate and achieves the skopos. Because if they thought that the translation fails to achieve the skopos, they will try to refine it until a better version is created. Since the translators are merely possible to admit that they failed to achieve the skopos, the skopos of the translation is "always" achieved.

Since the skopos is ambiguous, so whether the translation is in accordance with the Skopos Theory is all judged by the evaluator's own knowledge. He or she can give a translation that is in his mind a good translation that conforms to the Skopos Theory, however, may be not a good translation that really satisfies skopos. Let's see one example.

原文: 永远把人民对美好生活的向往作为奋斗目标,

译文: The aspirations of the people to lie a better life must always be the focus of our efforts...

Chang Su and Jie Wang think that for this translation, the passive voice in Chinese is translated into active voice and this transformation avoids the English version to be top-heavy and satisfies the using habits of English language. And they think this translation is in accordance with the skopos rule. In my opinion, transformation of voice is advisable; however, "focus of our efforts" can be seen as redundant because the word "focus" contains the meaning of "effort" in English. Jian Guo Wang and Bi Yu Wu analyze the difference in aesthetics between Chinese and English and conclude that Chinese language is aesthetically redundant while English language is aesthetically concise. Due to the difference in aesthetics, "of our efforts" can be deleted. This can also be explained by Skopos Theory and prove that Skopos Theory is unfalsifiable. Because if we regard a translation as a good translation, we can say that it is in accordance with the Skopos Theory, however, if the shortcomings or impropriety of the original version is found and a better translation is created, it can also be said that the new version conforms to the Skopos Theory. So in this sense, Skopos Theory is unfalsifiable and this is also one of the shortcomings of Vermeer's theory.

\subsubsection{The Ambiguity of Evaluation Criterion of Target Text (TranslaTUM)}

What is the evaluation criterion of the target text? In Skopos Theory, skopos is at a paramount place, and translators can have a lot of freedom and subjectivity in a translation process. For these translations which have achieved their skopos are regarded as good translations, and for those translations which have failed to achieve their skopos are categorized as bad translations. However, how to judge whether the translator has achieved the skopos? From the analysis in 3.2.1, we know that the skopos of a translation is ambiguous. If we regarding achieving the skopos as the requirements of a good translation, since the skopos is ambiguous, how do we judge whether a translation achieves the skopos or not? Let's see an example.

$$
\text { 原文: Coca Cola }
$$




\section{译文: 可口可乐}

For the translation of “Coca Cola" into Chinese, “可口可乐” seems to be a great and well-accepted one. If we see it from the perspective of Skopos Theory, we can only say that it accords with the Skopos Theory and it is a good translation. But how we determine the skopos specifically and how we judge whether this translation achieves the skopos by giving explanations in detail? So Skopos Theory can only be seen as a general theory and it gives us enlightenment that we should take the skopos of the translation into consideration, however, has no practical guiding meaning in the later translation process.

As the ambiguity of the skopos, it is infeasible to regarding achieving the skopos as the requirements of a good translation. Then some people begin to regard the other two rules: fidelity rule and coherence rule as the evaluation criteria for the target text. For example, Jian Jun Chen, in his A Study of the Chinese translation of Bobos in Pradise: A New Upper Class and How They Got There in the Light of the Skopos Theory, uses coherence rule and fidelity rule as the evaluation criteria for the target text. He analyzes many translations' impropriety by showing that they are contradictory to the coherence rule and fidelity rule; however, without realizing that skopos rule is the most important rule in Skopos Theory. Such case is not rare, quite a number of scholars will do this similar thing. For another example, when evaluating the translation of political documents, Chang Su and Jie Wang use all these three rules separately as ways to evaluate whether a translation is good or not. This is inappropriate and conflicting with the skopos rule, because according to Skopos Theory, the hierarchical rule of these three rules is that skopos rule $>$ coherence rule $>$ fidelity rule. Coherence rule and fidelity rule are subordinated to the skopos rule, and the skopos rule, rather than the other two rules, should be the evaluation criteria for the target text.

According to Vermeer, readers play the most important role in influencing the skopos of a translation, and translation is the target text produced in a specific situation for a specific skopos or for the target reader. In Skopos Theory, readers, as the most important role in influencing the skopos, should be the reviews of the translation. In this way, the target text that is well-accepted by the readers can be seen as good translation? Even if we regarding readers as the reviewers of the target text, how to deal with the different knowledge levels of the target reader? How to deal with the different aesthetic standards of the target reader?

From the above analysis, we can know that the evaluation criteria for a translation are ambiguous. From Skopos Theory, we know that, achieving the skopos rule, rather than the coherence rule and fidelity rule, should be the requirements of a good translation. However, due to the ambiguity of the skopos, it is infeasible to regard achieving the skopos as the requirements of a good translation. Even if we regard target readers, which according to Vermeer play the most important role in influencing the skopos, as the reviews of the translation, the 
problem of the difference in knowledge levels and aesthetic standards is still unmanageable.

\section{Conclusion}

Inspired by Wright's action theory, Vermeer regards translation as an intentional or purposeful action performed by human being. On this basis, Vermeer puts forward the Skopos Theory, mainly including three rules: skopos rule, coherence rule and fidelity rule, and the hierarchical rule of these three rules is that: skopos rule $>$ coherence rule $>$ fidelity rule. Since the birth of Vermeer's skopos rule, it has attracted a lot of attention and criticism. On the basis of the previous evaluation of Vermeer's Skopos Theory, this paper gives a critical thinking about Skopos Theory by talking briefly about the significance and the shortcomings of Skopos Theory in detail. Skopos Theory has much significance. Skopos Theory marks a shift of translation theory from a mere linguistic level to a more complex level and it makes people have a new thinking about the involving participants of a translational action. Skopos Theory gives the translator more freedom. It gives a new criterion for translation evaluation and gives certain attention to the target reader. However, it also has some shortcomings. The skopos is an ambiguous concept and Skopos Theory is unfalsifiable. Skopos Theory undervalues the source text and writers and it fails to give clear evaluation criteria for a translation. For the translation of some writings, such as advertisements and product manual, it is more convincing; however, for the translation of some writings such as literature, which contains high literariness and artistry, Skopos Theory seems a little far-fetched. So Skopos Theory is applicable in some limited areas, where the function of the writings is highly valued.

\section{Conflicts of Interest}

The author declares no conflicts of interest regarding the publication of this paper.

\section{References}

[1] Nord, C. (2001) Translating as a Purposeful Activity: Functionalist Approached Explained. Shanghai Foreign Language Education Press, Shanghai.

[2] 王婉玲. 冯.赖特行动逻辑研究[D]: [硕士学位论文]. 广州: 华南师范大学, 2004.

[3] Vermeer Hans, J. (1987) What Does It mean to Translate? Indian Journal of Applied Linguistics, 13, 25-33.

[4] Holz-Manttari, J. (1984) Translatorisches Handeln: Theorie und Methode. [Translational Action: Theory and Method.]. Suomalainen Tiedeakatemia, Helsinki.

[5] Munday, J. (2001) Introducing Translation Studies: Theories and Applications. Routledge, London and New York.

[6] Reiss, K. and Vermeer, H.J. (1984) Grubdlegung einer allgemeinen Translationstheorie. [Groundwork for a General Theory of Translation.] Niemeyer, Tubingen. https://doi.org/10.1515/9783111351919

[7] 王鹏. 《翻译理论探讨》一一对当代西方翻译理论的批判性认识[J]. 中国翻译 
2010, 31(03): 33-37.

[8] 张南峰. 中西译学批评 $[M]$. 北京: 清华大学出版社, 2004.

[9] 陈大亮. 针对翻译目的论的一种批判性反思一一兼论文学翻译主体性的困境[J]. 西安外国语大学学报, 2007(3): 49-52.

[10] 王振平, 任东升. 目的与方法一一对《尤利西斯》两个中译本的再思考 [J]. 外语 研究, 2006(1): 52-56.

[11] 刘宓庆. 中西翻译思想比较研究[M]. 北京: 中国对外翻译出版公司, 2005 . 